\title{
Automatized Separation of Fractions from Petroleum Based on Spectrophotometric Signal Derivative Using Open-Source Hardware for the Determination of Ni and V Linked to Porphyrins
}

\author{
Daniel M. Silva, ${ }^{a}$ Álvaro J. Pereira, ${ }^{a}$ Tatiana D. Saint'Pierre, ${ }^{a}$ Pierre M. Esteves, ${ }^{\circledR} * b$ \\ Anderson A. Rocha, ${ }^{\circledR c}$ Rainério Escalfoni Jr. ${ }^{d}$ and Christiane Duyck ${ }^{*, c}$ \\ ${ }^{a}$ Pontifícia Universidade Católica do Rio de Janeiro (PUC-Rio), \\ R. Marquês de São Vicente, 225, 22451-900 Rio de Janeiro-RJ, Brazil \\ ${ }^{b}$ Instituto de Química, Universidade Federal do Rio de Janeiro (UFRJ), \\ 21941-909 Rio de Janeiro-RJ, Brazil \\ ${ }^{c}$ Departamento de Química Analítica, Universidade Federal Fluminense (UFF), \\ Outeiro São João Batista, s/n, Centro, 24020-141 Niterói-RJ, Brazil \\ ${ }^{d}$ Centro de Pesquisa Leopoldo Américo Miguez de Mello (Cenpes), Petrobras, \\ Av. Jequitibá, 950, Cidade Universitária, 21941-598 Rio de Janeiro-RJ, Brazil
}

\begin{abstract}
An automated method based on open-source hardware was created for the separation of porphyrins fractions from crude oil, an essential step for the quantification of $\mathrm{V}$ and $\mathrm{Ni}$ as metalloporphyrins. Preparative liquid chromatography was implemented with a reverse phase gradient from $\mathrm{MeOH}$ to toluene. The system allows three solvents and fractions changes by using quaternary valves connected to an Arduino microcontroller, programmed on the basis of the absorbance signal measured and its first derivative. Additionally, the method was applied to crude oils (Venezuelan National Institute of Standards and Technology (NIST) 8505 and from a marine reservoir). $\mathrm{V}$ and $\mathrm{Ni}$ were determined by inductively coupled plasma mass spectrometry (ICP-MS) and the V-porphyrin profile was determined by high performance liquid chromatography (HPLC)-ICP-MS. The concentrations of the metals grow in the last eluting toluene fractions, associated with asphaltenes. On the other hand, V-porphyrins in the first eluting $\mathrm{MeOH}$ fractions showed profiles of labile compounds, with a higher percentage in the Brazilian crude oil (4.9 $\mathrm{mg} \mathrm{L}^{-1}$, corresponding to $18 \%$ of total V), in comparison to the one from the biodegraded NIST 8505 (59 $\mathrm{mg} \mathrm{L}^{-1}$, corresponding to $7 \%$ of total $\mathrm{V}$ ). The overall methodology has a good reproducibility and provides information on elements concentrations associated with porphyrin class compounds.
\end{abstract}

Keywords: automated separation, V and Ni porphyrins, absorbance derivative, ICP-MS, HPLC-ICP-MS, open-source scientific hardware

\section{Introduction}

Vanadium and nickel occurrence and stability in crude oils result from their complexation with porphyrins, which are tetrapyrrolic structures with high carbon number $\left(>\mathrm{C}_{20}\right)$ that vary with origin and oil maturity. ${ }^{1-3}$ The total $\mathrm{V}$ and Ni contents in crude oils are commonly determined in the industry with different objectives, such as in geochemical studies $^{4-8}$ or for petroleum refining, in order to prevent catalyst fouling. ${ }^{9}{ }^{10}$ Accurate and reproducible results are achieved with atomic spectrometries, and authors have

*e-mail: pesteves@iq.ufrj.br; cbduyck@id.uff.br reported good analytical performances and faster analysis with the direct introduction of the samples diluted in solvents in inductively coupled plasma mass spectrometry (ICP-MS), instead of their microwave assisted acid decomposition. ${ }^{11-13}$

Recently, the growing interest for the hydroprocessing of heavy crude oils and distillation residues containing high metalloporphyrin contents have urged a better understanding of the structure and distribution of these compounds in the distillation fractions of petroleum, in order to predict demetalization strategies. ${ }^{14-16}$ The fractionation of petroleum in a laboratory scale is usually performed by chromatographic techniques, such as 
preparative liquid chromatography (LC) and thin layer chromatography (TLC). The separation process is based on compounds elution in solvents or solvent mixtures with increasing polarity, and the obtained fractions are saturated hydrocarbons (S), aromatics and N, S, O compounds (A), resin $(\mathrm{R})$ and asphaltenes (A), the latter being the heaviest, with structural similarity to coke. The results are expressed as mass percentage and the overall methodology is known as SARA. ${ }^{17-19}$ The American Society for Testing and Materials (ASTM) method for SARA ${ }^{20}$ is based on LC, the oil sample is deasphaltened and further deposited on a sorbent (silica gel or alumina) and separated into its SAR fractions.

Authors have observed that the metalloporphyrins are mostly concentrated in the resin and asphaltenes (RA) fractions, associated with high molecular weight macrocycles, which are poorly separated when using size exclusion chromatography (SEC) or SEC-ICP-MS. ${ }^{21-24}$ Conversely, $\mathrm{V}$ and Ni porphyrins in the aromatics fraction are more labile, due to the presence of small polar molecules that act as solvents, increasing mobility. ${ }^{25}$ The lability of those smaller and more polar compounds allow to employ a reverse phase separation, which results in improved resolutions, when compared to TLC or SEC. In this case, the separation is based on the difference between the less polar $\mathrm{Ni}^{2+}$-tetrapyrrole planar complexes and the more polar $\mathrm{VO}^{2+}$ squared pyramidal forms. ${ }^{26-28}$ Besides, $\mathrm{V}$ and Ni metalloporphyrins can have a high number of substitutions, from aliphatic chains, such as in deoxophylloerythroetioporphyrin (DPEP) and etioporphyrin families, to aromatic or carboxyl groups. Then, adaptations of conventional SARA and TLC methods were necessary, in order to obtain cleaner fractions of neutral, polar and acidic metalloporphyrins, and improve their ionization process in Fourier transform ion cyclotron resonance mass spectrometry (FT-ICR-MS). ${ }^{28-31}$

Additionally, UV-Vis spectrophotometry can be used to control the fractionation of metalloporhyrins, ${ }^{32}$ because they exhibit specific absorption bands, one being the Soret band (around $400 \mathrm{~nm}$ ), with a high absorptivity due to $\pi-\pi^{*}$ transition of the porphyrin nucleus. ${ }^{33}$ Automated versions of this technique are attractive, because they require a minimum of operation, reduce solvent consumption, improve precision and allow easily multiple steps..$^{34,35}$

Automation and maker/do-it-yourself (DIY) culture will play a key role in the so-called fourth industrial revolution (Industry 4.0). As such, automation in flow chemistry will surely contribute for such important strategic movement, by applying the open-source concept. ${ }^{36} \mathrm{We}$ propose an automated method by using open-source hardware for petroleum fractionation based on the porphyrin absorption derivative at $400 \mathrm{~nm}$. The signal derivatives are commonly employed in real time data processing for peak detection and quantification, particularly in the case of complex mixtures that result in peaks superposition. ${ }^{37,38}$ However, the objective was to effectively separate absorbing fractions without further peak processing, therefore, a simple mathematical approach, based on the first and fourth derivatives and without smoothing algorithms, is employed. National Instruments LabVIEW ${ }^{\mathrm{TM} 39}$ is used to program an Arduino microcontroller for the control of valves and the separation of the metalloporphyrin fractions eluted with a reverse gradient, from methanol to toluene. Total $\mathrm{V}$ and $\mathrm{Ni}$ in these fractions are determined by ICP-MS after dilution in xylene and $\mathrm{V}$ linked to porphyrins is determined by high performance liquid chromatography (HPLC)-ICP-MS. The proposed automatized methodology has the advantage of improving the porphyrins class separation, when comparing to the automatized methods employing TLC, in order to quantify $\mathrm{V}$ and $\mathrm{Ni}$ linked to metalloporphyrins.

\section{Experimental}

\section{Samples, reagents and standards}

A crude oil (O-1) with American Petroleum Institute (API) degree of 21.9 , density of $0.9187 \mathrm{~g} \mathrm{~cm}^{-3}$ and viscosity at $40{ }^{\circ} \mathrm{C}$ of $1.94 \mathrm{~cm}^{2} \mathrm{~s}^{-1}$, from an onshore reservoir and used as an internal reference in our laboratory, ${ }^{40}$ was used for the development of the methodology, which was also applied to a Venezuelan certified crude oil, National Institute of Standards and Technology (NIST) 8505 and a crude oil A of marine influence. The oils $(0.5 \mathrm{~g})$ were pre-fractionated on a gravimetric glass column $\left(50 \times 2.5 \mathrm{~cm}^{2}\right)$, using a gradient elution of heptane-toluene-dichloromethane-methanol/ chloroform/water (65/35/4, v/v/v). ${ }^{41}$ Two fractions were obtained: (i) paraffins, aromatics and polar compounds (PAP); and (ii) RA, with mass recoveries higher than $85 \%$. This first separation was necessary, in order to minimize the contamination of the RA fraction during the automated separation. All solvents used for fractionation were of HPLC grade (J.T. Baker). Xylene (analytical grade, Vetec, Sigma-Aldrich) was used for the dilution of the crude oils, fractions and the calibration solutions, prepared with S-21 multielemental organic standard (SCP Science) in a concentration range from 5 to $80 \mathrm{ng} \mathrm{g}^{-1}$, for $\mathrm{Ni}$ and $\mathrm{V}$ determination by ICP-MS. ${ }^{42} \mathrm{~A}$ standard of vanadyl octaethylporphine (Aldrich) was used for detector calibration. The NIST standard reference materials 1084a, certified in $\mathrm{Ni}$ and $\mathrm{V}$, and 8505, certified in $\mathrm{V}$, were used for accuracy assessment of total concentrations in fractions. The HPLC-ICP-MS method for V determination in the 
labile metalloporphyrins fractions was applied to the samples. ${ }^{41}$

\section{System assembly}

The overall procedure can be divided into three subsystems: (i) injection and solvents pumping; (ii) detection; and (iii) fractions separation, all connected to an Arduino Uno SMD R3 microcontroller with an ATmega16U2 USB-to-serial converter and a National Instruments LabVIEW ${ }^{\mathrm{TM} 39}$ interface program.

A glass demountable column $\left(25 \times 2.5 \mathrm{~cm}^{2}\right.$; Supelco/ Sigma-Aldrich) filled with about $30 \mathrm{~g}$ of silica gel (63-200 mm, Merck), activated at $150{ }^{\circ} \mathrm{C}$, is used for the automated fractionation of the PAP or RA fractions by liquid chromatography and the gel is discarded at the end of the process. The sample and the solvents are pumped on the column with a peristaltic pump (Minipuls 3 , Gilson). Two valves (12 V, Rheodyne) with 4 inlets and 1 outlet are used in the process, one for injection and solvents selection, and the other for fraction separation. The column is connected to a $0.45 \mathrm{~mL}$ quartz flow cell (Hellma) with a $1 \mathrm{~cm}$ optical path length, where absorption occurs. All connections and tubing are made of Teflon or polyetheretherketone (PEEK).

The detection subsystem consists of a source and photovoltaic cell detector, both fixed and carefully aligned on the optical path of the flow cell in a homemade support, where it can be inserted or removed. The source is a $400 \pm 5 \mathrm{~nm}$ light-emitting diode (LED) with a high brightness $(12 \mathrm{~mW}), 3.7 \mathrm{~V}$ forward voltage at $20 \mathrm{~mA}$ (L3-0-U5TH15-1, LED Supply) and a $15^{\circ}$ irradiation half angle with a low reverse current $(10 \mu \mathrm{A}$ at $5 \mathrm{~V})$. The detector is a negative-positive-negative (NPN) silicon phototransistor (TIL 78, Texas Instruments) packed in a LED, operating at minimum of $1 \mathrm{~mA}$ light current and $5 \mathrm{~V}$. The phototransistor voltage was amplified with rotatory potentiometers (100 and $2 \mathrm{k} \Omega, \pm 3 \%$, P47221B Amphenol), at a constant gain. This open-source hardware assembly has been successfully used by authors in photometric circuits. ${ }^{37,38,43}$ Details of the circuit protoboard, circuit schematics and Arduino program, as well as the LabVIEW $^{\text {TM39 }}$ program interface (.txt) are available in the Supplementary Information section.

\section{Automated separation of porphyrins fractions}

The PAP fraction (about $0.4 \mathrm{~g}$ ) is dissolved in about $1 \mathrm{~mL}$ of toluene and automatically injected at $1.4 \mathrm{~mL} \mathrm{~min}^{-1}$, corresponding to the position 1 of the valves 1 and 2 (the simplified scheme is shown in Figure 1). Then, the valve 1 is switched to position 2 and the peristaltic pump is adjusted to $1.2 \mathrm{~mL} \mathrm{m^{-1 }}$ for methanol elution, data acquisition begins and the non-absorbing fraction is separated. When

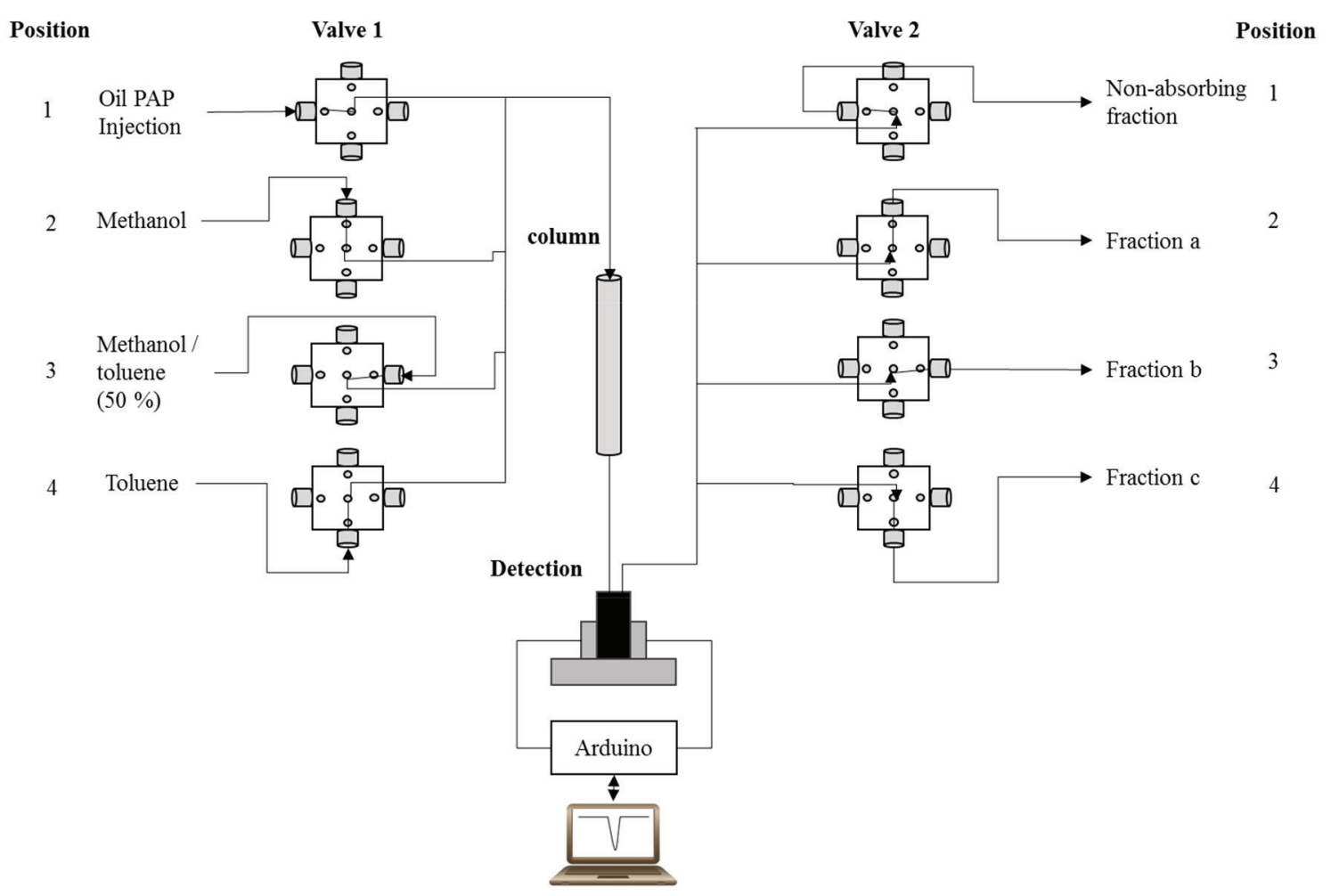

Figure 1. Scheme of the automated fractionation system and positions adopted by the two valves. 
Table 1. Conditions of absorbance variation for peak definition and valves change, defined by the automation program. The repetition of dA threshold settled by $\operatorname{var}_{\text {peak }}(|\mathrm{dA}|)$ is listed with the number of time intervals

\begin{tabular}{lccc}
\hline Peak elution & Variable value & $|\mathrm{dA}|$ & Action controlled by Arduino \\
\hline Beginning of peak 1 & $\operatorname{var}_{\text {Bool }}=1, \operatorname{var}_{\text {peak }}=1$ & $|\mathrm{dA}|>0.01(3 \times \mathrm{dt})$ & valve 2: position 2 \\
End of peak 1 & $\operatorname{var}_{\text {Bool }}=1, \operatorname{var}_{\text {peak }}=0$ & $|\mathrm{dA}|<0.001(5 \times \mathrm{dt})$ & valve 1: position 3 \\
& & & valve 2: position 3 \\
Beginning of peak 2 & $\operatorname{var}_{\text {Bool }}=2, \operatorname{var}_{\text {peak }}=1$ & $|\mathrm{dA}|>0.005(5 \times \mathrm{dt})$ & no action \\
End of peak 2 & $\operatorname{var}_{\text {Bool }}=2, \operatorname{var}_{\text {peak }}=0$ & $|\mathrm{dA}|<0.0006(5 \times \mathrm{dt})$ & valve 1: position 4 \\
Beginning of peak 3 & $\operatorname{var}_{\text {Bool }}=3, \operatorname{var}_{\text {peak }}=1$ & $|\mathrm{dA}|>0.005(5 \times \mathrm{dt})$ & valve 2: position 4 \\
End of peak 3 & $\operatorname{var}_{\text {Bool }}=3, \operatorname{var}_{\text {peak }}=0$ & $|\mathrm{dA}|<0.001(5 \times \mathrm{dt})$ & no action \\
\hline
\end{tabular}

$|\mathrm{dA}|$ : absolute value of absorbance variation $(\mathrm{dA})$; $\operatorname{var}_{\text {Bool }}$ : Boolean variable; $\operatorname{var}_{\text {peak }}$ : peak counter variable; $\mathrm{dt}$ : time interval $(\mathrm{dt}=10 \mathrm{~s})$.

the beginning of the first peak is detected, the valve 2 is automatically switched to position 2, for the separation of the first absorbing fraction (fraction a). At the end of fraction a elution, the valves 1 and 2 are switched to position 3 , and the $50 \%(\mathrm{v} / \mathrm{v})$ methanol/toluene mixture is pumped into the column, whereas the second absorbing fraction (fraction b) is separated. Again, at the end of fraction b elution, both valves are changed to position 4 , for toluene pumping and separation of the third absorbing fraction (fraction c). At the end of the third peak, data acquisition is maintained for $5 \mathrm{~min}$ because a fourth peak can occur, depending on the original crude oil. Then, the elution and program are stopped. The program also has a time threshold at $90 \mathrm{~min}$, when it is stopped if the third peak has not yet been detected. The overall sequence is listed in Table 1.

\section{Results and Discussion}

\section{System optimization and data acquisition}

The calibration of the detection subsystem was performed with the vanadyl octaethylporphine standard and the response was linear in a concentration range from 0.3 to $2 \mu \mathrm{mol} \mathrm{L}^{-1}\left(\mathrm{r}^{2}=0.91\right)$. A molar absorptivity of $403 \mathrm{mmol} \mathrm{L}^{-1} \mathrm{~cm}^{-1}$ was obtained from the inclination of the curve, which was similar to another published result $\left(364 \mathrm{mM}^{-1} \mathrm{~cm}^{-1}\right)$ obtained with a spectrophotometer. ${ }^{33}$ The overall detection system presents a good sensitivity, with a dark current of $0.01 \mathrm{~V}$.

The transmittance is the ratio of the irradiance power when no absorbing compound is eluted $\left(\mathrm{P}_{0}\right)$ to the one in the presence of absorbing compounds $(\mathrm{P})$. At constant gain, the transmittance can be simplified as the ratio of the corresponding voltages: $\mathrm{V}_{0} / \mathrm{V}$. Then, the absorbance of the eluent is calculated as:
$\mathrm{A}=-\log \left(\mathrm{V} / \mathrm{V}_{0}\right)$

The program calculated the first derivative $(\mathrm{dA} / \mathrm{dt})$ from average values of the measured absorbance (A) during a settled time interval of $\mathrm{dt}=10 \mathrm{~s}$, which is a compromise between the peaks circumvolution and the baseline fluctuations. The derivative is calculated as:

$(\mathrm{dA} / \mathrm{dt})_{\mathrm{n}+1}=\left(\mathrm{A}_{\mathrm{n}+1}-\mathrm{A}_{\mathrm{n}}\right) / \mathrm{dt}$

where $d A=A_{n+1}-A_{n}$ is the absorbance variation of the eluent within the time interval. Since only dA varies, its values are used for comparison with threshold values, in order to define the elution of absorbing compounds, and to send the information to the Arduino, which controls the system. The variations of $\mathrm{A}$ and $\mathrm{dA} / \mathrm{dt}$ during the separation of about $0.3 \mathrm{~g}$ of PAP fraction obtained from crude oil O-1 can be seen in Figure 2. In this case, the cuts of the fractions ( $a, b$, c) are adjacent, because these were used for V-porphyrin analysis by HPLC-ICP-MS. The first peak was determined between 50.8 and $93.8 \mathrm{~min}$, the second one between 147 and $212.2 \mathrm{~min}$, and the third one between 256.2 and $285.2 \mathrm{~min}$.

\section{Conditions and control of the valves}

The program uses a peak counter variable, named var ${ }_{\text {peak }}$, which establishes conditions for $\mathrm{dA}$ absolute values $(|\mathrm{dA}|)$ for the definition of a peak. In parallel, a Boolean variable, named var $_{\text {Bool }}$, tests the conditions imposed by var ${ }_{\text {peak }}$ and the change of var $_{\text {Bool }}$ from "false" to "true" happens when $|\mathrm{dA}|$ is significantly above or below a threshold value imposed by $v_{\text {peak }}$, indicating the beginning or the end of a peak. The program starts to test $|\mathrm{dA}|$ for $\operatorname{var}_{\text {Bool }}$ after $15 \mathrm{~min}$ of elution. It sends commands to the Arduino by the serial port when any of these thresholds are crossed, in order to control the valves. The threshold values and conditions 


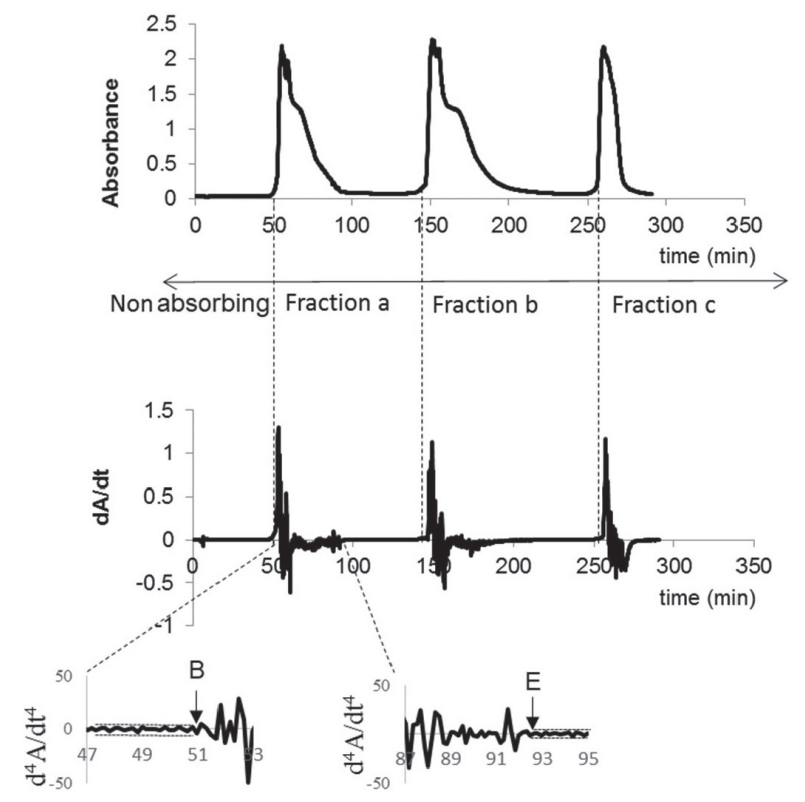

Figure 2. Variation of absorbance $(400 \mathrm{~nm})$ and its derivative $(\mathrm{dA} / \mathrm{dt})$ as a function of time, with the fractions cuts. Details of the fourth derivative $\left(\mathrm{d}^{4} \mathrm{~A} / \mathrm{dt}^{4}\right)$ are shown at the beginning (B) and end (E) of the first peak.

are listed in Table 1 and were determined with precision after a first elution of the PAP fraction. Considering that the noise function $(\mathrm{f}(\mathrm{x}))$ is oscillatory and results from the sinusoidal current function, when the absorbance function $(\mathrm{g}(\mathrm{x}))$ depends on Beer's Law, then according to Leibniz's equation, the derivative of $\mathrm{n}^{\text {th }}$ order is:

$(f(x) \times g(x))^{n}=\sum_{i=0}^{n}\left(\begin{array}{l}n \\ i\end{array}\right) f^{(n-i)}(x) \times g^{(i)}(x)$

Admitting that the $\mathrm{k}$ coefficient in the noise sinusoidal function $\mathrm{f}(\mathrm{x})=\sin (\mathrm{kx})$ is below unity, then the $\mathrm{n}^{\text {th }}$ derivative:

$\mathrm{k}^{\mathrm{n}} \sin \left(\mathrm{kx}+\mathrm{n} \frac{\pi}{2}\right)$

tends to zero and lowers the corresponding terms in the Leibniz equation. Usually, the fourth derivative is satisfactory for noise attenuation in signal processing, and the beginning and end of peaks is visible when $\mathrm{d}^{4} \mathrm{~A} / \mathrm{dt}^{4}$ is different from the baseline such as in the Figure 2 details of the first peak elution. Then, the threshold values are the corresponding $|\mathrm{dA}|$ values found at the $\mathrm{B}(|\mathrm{dA}|=0.01)$ and $\mathrm{E}(|\mathrm{dA}|=0.001)$ points.

As it can be inferred from the numbers of peaks in the $\mathrm{d}^{4} \mathrm{~A} / \mathrm{dt}^{4}$ plot as a function of time, there is a plurality of eluting compounds, considering that porphyrins without $\mathrm{V}$ and $\mathrm{Ni}$, as well as other aromatic compounds, can absorb at $400 \mathrm{~nm}$ and the fractions did not contain exclusively these metalloporphyrins. After complete separation, the program shuts down the system and generates a txt archive that can be used for the $A=f(t)$ and derivatives graphs, as exemplified in Figure 2.

\section{Determination of $\mathrm{Ni}$ and $\mathrm{V}$ in fractions by ICP-MS}

Total $\mathrm{V}$ and $\mathrm{Ni}$ concentrations in the original samples and in the porphyrins fractions were determined by ICP-MS after dilution in xylene. The solutions were introduced into the instrument at a $0.1 \mathrm{~mL} \mathrm{~min}{ }^{-1}$ aspiration rate with a micronebulizer (PFA-100, Elemental Scientific) coupled to a cyclonic spray chamber refrigerated at $5{ }^{\circ} \mathrm{C}$ (ISOMIST ${ }^{\mathrm{TM}}$, Glass Expansion) and the ICP-MS was operated at a forward power of $1.3 \mathrm{~kW}$, Ar flows of 17 (plasma), 1.2 (auxiliary) and $0.4 \mathrm{~L} \mathrm{~min}^{-1}$ (nebulizer) with addition of $0.1 \mathrm{~L} \mathrm{~min}^{-1} \mathrm{O}_{2}$ (nebulizer). The analysis of NIST 1084a, certified in V $\left(95.9 \pm 9.4 \mathrm{mg} \mathrm{kg}^{-1}\right)$ and $\mathrm{Ni}\left(99.7 \pm 1.6 \mathrm{mg} \mathrm{kg}^{-1}\right)$, resulted in recoveries between 90 and $95 \%$, respectively, and NIST 8505, certified in V $\left(390 \pm 10 \mathrm{mg} \mathrm{kg}^{-1}\right)$, resulted in a recovery of $103 \%$. Limits of detection (LOD) were calculated as 3 times the standard deviation of 10 measurements of signals in xylene divided by the slopes of the calibration curves, and the values were $0.4\left({ }^{51} \mathrm{~V}\right)$ and $0.1 \mu \mathrm{g} \mathrm{kg}^{-1}\left({ }^{60} \mathrm{Ni}\right)$. The LODs were of the same order or better than those reported in previous works. ${ }^{22,42}$

The samples O-1 and NIST 8505 were previously separated into their PAP and RA fractions and the PAP fractions were separated with the automatized method for the quantification of $\mathrm{V}$ and $\mathrm{Ni}$ in fractions $\mathrm{a}, \mathrm{b}$ and $\mathrm{c}$ (PAP) and RA. The reproducibility of the automatized separation methodology was evaluated through the standard deviations of the quadruplicate of O-1 PAP fractions and the results, all lower than $10 \%$, are presented in Table 2. These results show the potentiality of the automatized method in terms of reproducible data, considering all the uncertainties associated with a chromatographic fractionation. In the case of NIST 8505, the reproducibility study was not carried out, due to the low amount of sample available in the lab and, therefore, the results are reported for one replicate.

From the point of view of the oils compositions, the NIST 8505 certified crude oil showed higher metalloporphyrins content than crude oil O-1. This difference can be attributed to the higher biodegradation stage of the Venezuelan NIST 8505 oil, in comparison to the Brazilian O-1 oil. In addition, the elemental mass balances were calculated as the sum of the quantities of the element (concentration $\times$ mass) in fractions $a, b, c$ (if analyzed) and RA, divided by its quantity in the oil. The values were $83 \%$ for both $\mathrm{V}$ and $\mathrm{Ni}$ in sample $\mathrm{O}-1$ and $64(\mathrm{~V})$ and $67 \%(\mathrm{Ni})$ in NIST 8505. It can also be noted that, in the case of $\mathrm{O}-1, \mathrm{~V}$ in the labile fraction (fraction a) 
Table 2. V and Ni concentrations in porphyrin fractions (a to c), and in the RA fractions of crude oil samples O-1 and NIST 8505, separated automatically

\begin{tabular}{|c|c|c|c|c|c|c|c|c|c|c|c|c|c|}
\hline & \multicolumn{8}{|c|}{ Crude oil O-1 } & \multicolumn{5}{|c|}{ NIST 8505} \\
\hline & Oil & $\begin{array}{c}\text { Fraction } \\
\mathrm{a}\end{array}$ & $\begin{array}{c}\text { Fraction } \\
\mathrm{b}\end{array}$ & $\begin{array}{c}\text { Fraction } \\
\mathrm{c}\end{array}$ & RA & $\begin{array}{c}\text { Fraction } \\
\mathrm{d}\end{array}$ & $\begin{array}{c}\text { Fraction } \\
\mathrm{e}\end{array}$ & $\begin{array}{c}\text { Fraction } \\
\mathrm{f}\end{array}$ & Oil & $\begin{array}{c}\text { Fraction } \\
\mathrm{a}\end{array}$ & $\begin{array}{c}\text { Fraction } \\
\mathrm{b}\end{array}$ & $\begin{array}{c}\text { Fraction } \\
\mathrm{c}\end{array}$ & RA \\
\hline Mass / g & 1.0 & $\begin{array}{c}0.28 \pm \\
0.01\end{array}$ & $\begin{array}{c}0.26 \pm \\
0.02\end{array}$ & $\begin{array}{c}0.016 \pm \\
0.01\end{array}$ & $\begin{array}{c}0.25 \pm \\
0.01\end{array}$ & $\begin{array}{c}0.10 \pm \\
0.01\end{array}$ & $\begin{array}{c}0.053 \pm \\
0.001\end{array}$ & $\begin{array}{c}0.045 \pm \\
0.005\end{array}$ & 1.0 & $\begin{array}{c}0.36 \pm \\
0.03\end{array}$ & $\begin{array}{c}0.24 \pm \\
0.03\end{array}$ & $\begin{array}{c}0.023 \pm \\
0.002\end{array}$ & $\begin{array}{c}0.242 \pm \\
0.004\end{array}$ \\
\hline $\mathrm{V} /\left(\mathrm{mg} \mathrm{kg}^{-1}\right)$ & $\begin{array}{c}9.2 \pm \\
0.1\end{array}$ & $\begin{array}{c}4.9 \pm \\
0.3\end{array}$ & $\begin{array}{c}4.0 \pm \\
0.3\end{array}$ & n.d. & $21 \pm 2$ & 13 & 28 & 31 & $\begin{array}{c}403 \pm \\
17\end{array}$ & 59 & 202 & 694 & $715 \pm 45$ \\
\hline $\mathrm{Ni} /\left(\mathrm{mg} \mathrm{kg}^{-1}\right)$ & $\begin{array}{c}22.1 \pm \\
0.1\end{array}$ & $\begin{array}{c}4.84 \pm \\
0.03\end{array}$ & $\begin{array}{c}14.0 \pm \\
0.2\end{array}$ & n.d. & $53 \pm 2$ & 15 & 53 & 85 & $52 \pm 4$ & 3.8 & 16.6 & 95 & $112 \pm 10$ \\
\hline
\end{tabular}

NIST: National Institute of Standards and Technology; RA: resin and asphaltenes; n.d.: not determined (fractionated). The standard deviations are reported for a quadruplicate of $\mathrm{O}-1$. The RA fraction of oil O-1 was also fractionated (fractions $\mathrm{d}$ to $\mathrm{f}$ ).

represents $15 \%$ of the element quantity in the oil, whereas this percentage lowers to $5 \%$ in the case of NIST 8505 . As it can be seen, the lability of vanadyl porphyrins decreases with increasing biodegradation of the sample, with a progressive incorporation of these compounds into lateeluting, low mobility fractions, such as fractions b and $c$.

In addition, fraction c from O-1 PAP and fraction RA from O-1 were gathered and again submitted to automated fractionation, as one replicate (Table 2). Similarly to the PAP fractionation, three fractions (d to f) were obtained, with $\mathrm{V}$ and $\mathrm{Ni}$ concentrations higher than in the original sample. Consequently, these fractions are consistent with an asphaltenic character and should not have significant quantities of labile compounds.

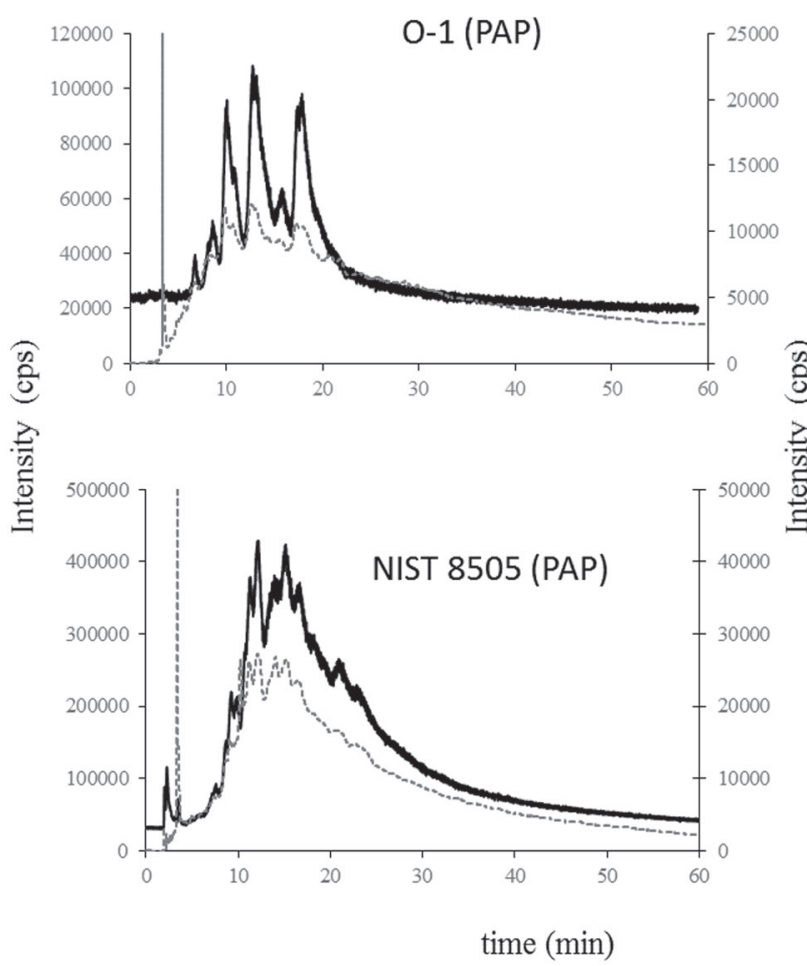

\section{Determination of V-porphyrins by HPLC-ICP-MS}

The interest of using a reversed phase elution program is in the selectivity obtained for the separation of labile $\mathrm{V}$-porphyrins, which are readily soluble in methanol. Qualitative determination of labile V-porphyrins was performed by analyzing fraction a obtained from duplicates of PAP of O-1 and NIST 8505, and from one PAP replicate of crude oil sample A, employing HPLC-ICP-MS. Fraction $\mathrm{d}$ from the resin fractionation of O-1 was also analyzed.

As it can be seen in Figure 3, the improvement in resolution regarding conventional SARA and SEC separation allows to distinguish between the $\mathrm{V}$-porphyrinic samples profiles. ${ }^{22,44}$ The $\mathrm{V}$ chromatograms of the labile

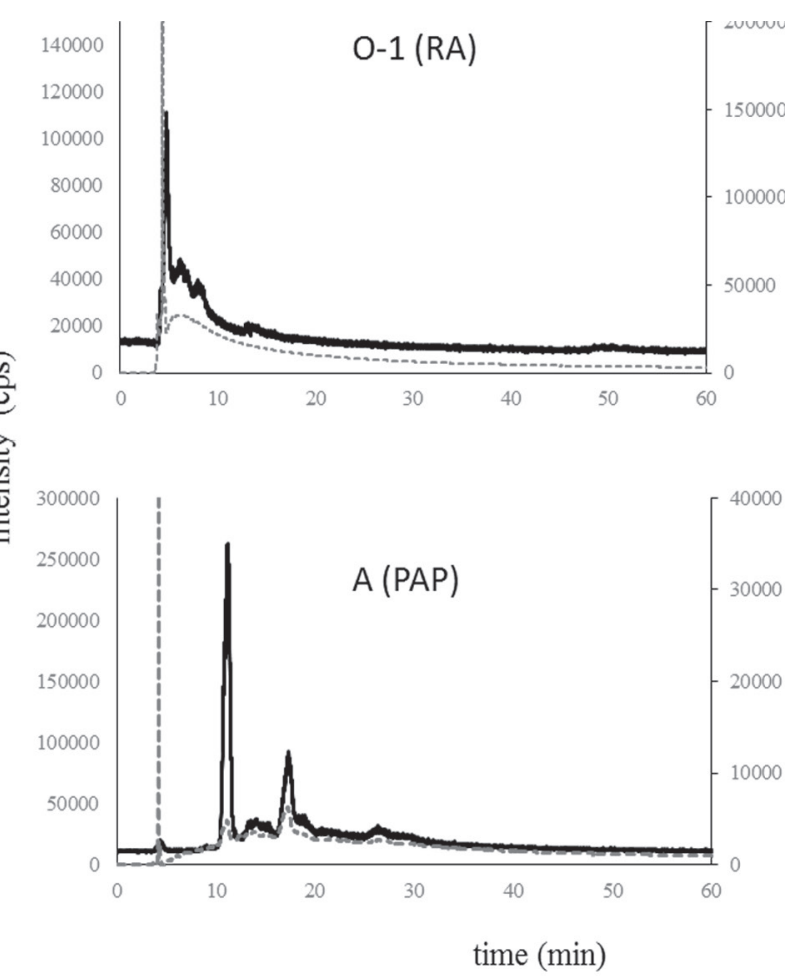

Figure 3. V linked to porphyrins in the labile fractions (fractions a and d) determined by HPLC-ICP-MS (HPLC: RP18 $150 \times 4.6$ and $125 \times 4 \mathrm{~mm}^{2}$ in series, $0.6 \mathrm{~mL} \mathrm{~min}{ }^{-1}$ methanol elution). Black line: ${ }^{51} \mathrm{~V}$ ICP-MS signal; gray dashed line: $400 \mathrm{~nm}$ HPLC photodiode array signal. 
fraction obtained for crude oils from different origins and biodegradation levels by HPLC-ICP-MS with two RP18 columns in series, using the methodology described in Wandekoken et al. ${ }^{41}$ show that the complexity of V-porphyrins rise with the biodegradation level (O-1 < NIST 8505). There is a profile difference between O- 1 and A, as well, from terrestrial and marine reservoirs, possibly related to the difference in bacterial activity. In the case of the O-1 RA fractionation (Figure 3), early elution of the $\mathrm{V}$ chromatogram suggests acid groups. The chromatograms obtained for the other fractions show unresolved peaks, which are a general profile observed for macromolecules such as asphaltenes.

\section{Conclusions}

The automated separation of metalloporphyrins fractions from crude oils was successfully performed on the basis of the absorbance derivatives at the Soret band of $400 \mathrm{~nm}$, for the control of the separation. The threshold values of the derivative $\mathrm{dA} / \mathrm{dt}$, imposed by the peak variable, were correctly defined for peaks separation, as observed by the significant change of the fourth derivative, $\mathrm{d}^{4} \mathrm{~A} / \mathrm{dt}^{4}$, from the attenuated baseline. A simple approach, employing two variables and absorbance derivative, could be used for the testing of the conditions of peak elution and the quantification of $\mathrm{V}$ and Ni by ICP-MS, with acceptable elemental mass balances. The reversed solvent program, from methanol to toluene, was employed for mobility comparison of V-porphyrins determined in the first eluting fraction by HPLC-ICP-MS obtained from the investigated crude oils and rise with the biodegradation level of the oil and from marine to onshore reservoirs. The overall methodology was simple to operate, consumed less solvent than the manual separation and generated reproducible fractions for quantitative results improvement. This method is versatile and can be adjusted for other fractionations based on absorbing chromophores, and we are currently working on an adapted version of the Labview program on open source software.

\section{Supplementary Information}

Supplementary data (scheme for circuit protoboard, circuit schematics, code for Arduino (.ino) and LabVIEW ${ }^{\mathrm{TM}}$ ) are available free of charge at http://jbcs.sbq.org.br.

\section{Acknowledgments}

The authors thank the Brazilian Petroleum Company (Petrobras) for the funding and in particular Flávio
Albuquerque, Marco Antônio Teixeira and Rosana Cardoso, for the valuable contributions in porphyrins separation. Also, the authors thank the Brazilian National Research Council (CNPq) for the grants.

\section{References}

1. Ocampo, R.; Callot, H. J.; Albrecht, P.; Kintzinger, J. P.; Tetrahedron Lett. 1984, 25, 2589.

2. Filby, R. H.; Van Berkel, G. J.; ACS Symp. Ser. 1987, 344, 2.

3. Ocampo, R.; Riva, A.; Trendel, J. M.; Riolo, J.; Callot, H. J.; Albrecht, P.; Energy Fuels 1993, 7, 191.

4. Doukkali, A.; Saoiabi, A.; Zrineh, A.; Hamad, M.; Ferhat, M.; Barbe, J. M.; Guilard, R.; Fuel 2002, 81, 467.

5. Galarraga, F.; Reategui, K.; Martïnez, A.; Martínez, M.; Llamas, J. F.; Márquez, G.; J. Pet. Sci. Eng. 2008, 61, 9.

6. Escobar, M.; Márquez, G.; Azuaje, V.; Da silva, A.; Tocco, R.; Fuel 2012, 97, 186.

7. Akinlua, A.; Sigedle, A.; Buthelezi, T.; Fadipe, O. A.; Mar. Pet. Geol. 2015, 59, 286.

8. López, L.; Lo Mónaco, S.; Org. Geochem. 2017, 104, 53.

9. Panariti, N.; Del Bianco, A.; Del Piero, G.; Marchionna, M.; Appl. Catal., A 2000, 204, 203.

10. Ali, M. F.; Abbas, S.; Fuel Process. Technol. 2006, 87, 573.

11. Duyck, C.; Miekeley, N.; Porto da Silveira, C. L.; Aucélio, R. Q.; Campos, R. C.; Grinberg, P.; Brandão, G. P.; Spectrochim. Acta, Part B 2007, 62, 939.

12. Sánchez, R.; Todolí, J. L.; Lienemann, C.-P.; Mermet, J.-M.; Spectrochim. Acta, Part B 2013, 88, 104.

13. Poirier, L.; Nelson, J.; Leong, D.; Berhane, L.; Hajdu, P.; LopezLinares, F.; Energy Fuels 2016, 30, 3783.

14. Rana, M. S.; Sámano, V.; Ancheyta, J.; Diaz, J. A. I.; Fuel 2007, 86, 1216.

15. Rana, M. S.; Ancheyta, J.; Sahoo, S. K.; Rayo, P.; Catal. Today 2014, 220-222, 97.

16. Jenifer, A. C.; Sharon, P.; Prakash, A.; Sande, P. C.; Energy Fuels 2015, 29, 7743.

17. Fan, T.; Buckley, J. S.; Energy Fuels 2002, 16, 1571.

18. Speight, J. G.; Oil Gas Sci. Technol. 2004, 59, 467.

19. Kharrat, A. M.; Zacharia, J.; Cherian, V. J.; Anyatonwu, A.; Energy Fuels 2007, 21, 3618.

20. ASTM D2007: Standard Test Method for Characteristic Groups in Rubber Extender and Processing Oils and Other PetroleumDerived Oils by the Clay-Gel Absorption Chromatographic Method, Philadelphia, 2016.

21. Merdrignac, I.; Espinat, D.; Oil Gas Sci. Technol. 2007, 62 , 7.

22. Caumette, G.; Lienemann, C.-P.; Merdrignac, I.; Bouyssiere, B.; Lobinski, R.; J. Anal. At. Spectrom. 2010, 25, 1123.

23. Barbier, J.; Marques, J.; Caumette, G.; Merdrignac, I.; Bouyssiere, B.; Lobinski, R.; Lienemann, C.-P.; Fuel Process. Technol. 2014, 119, 185. 
24. Vargas, V.; Castillo, J.; Torres, R. O.; Bouyssiere, B.; Lienemann, C.-P.; Fuel Process. Technol. 2017, 162, 37.

25. Cui, Q.; Nakabayashi, K.; Ma, X.; Miyawaki, J.; Ideta, K.; Tennichi, Y.; Ueda, M.; Al-Mutairi, A.; Marafi, A. M. J.; Park, J.-I.; Yoon, S.-H.; Mochida, I.; Energy Fuels 2017, 31, 4748.

26. Duyck, C.; Miekeley, N.; Fonseca, T. C. O.; Szatmari, P.; Santos Neto, E. V.; J. Braz. Chem. Soc. 2008, 19, 978.

27. Dechaine, G. P.; Gray, M. R.; Energy Fuels 2010, 24, 2795.

28. Rodgers, R. P.; Hendrickson, C. L.; Emmett, M. R.; Marshall, A. G.; Greaney, M.; Qian, K.; Can. J. Chem. 2001, 79, 546.

29. Zhao, X.; Liu, Y.; Xu, C.; Yan, Y.; Zhang, Y.; Zhang, Q.; Zhao, S.; Chung, K.; Gray, M. R.; Shi, Q.; Energy Fuels 2013, 27, 2874.

30. Kim, E.; Cho, E.; Moon, S.; Park, J.-I.; Kim, S.; Energy Fuels 2016, 30, 2932.

31. Putman, J. C.; Rowland, S. M.; Corilo, Y. E.; McKenna, A. M.; Anal. Chem. 2014, 86, 10708.

32. Sundararaman, P.; Anal. Chem. 1985, 57, 2204.

33. Foster, N. S.; Day, J. W.; Filby, R. H.; Alford, A.; Rogers, D.; Org. Geochem. 2002, 33, 907.

34. Grizzle, P. L.; Sablotny, D. M.; Anal. Chem. 1986, 58, 2389.
35. Boysen, R. B.; Schabron, J. F.; Energy Fuels 2013, 27, 4654.

36. Pearce, J. M.; Science 2012, 337, 1303.

37. Wittbrodt, B. T.; Squires, D. A.; Walbeck, J.; Campbell, E.; Campbell, W. H.; Pearce, J. M.; PLoS One 2015, 10, e0134989.

38. Kelley, C.; Krolick, A.; Brunner, L.; Burklund, A.; Kahn, D.; Ball, W.; Weber-Shirk, M.; Sensors 2014, 14, 7142.

39. National Instruments; LabVIEW version 14; National Instruments, USA, 2015.

40. Ford, S.; J. Pharm. Biomed. Anal. 2003, 33, 563.

41. Wandekoken, F. G.; Duyck, C. B.; Fonseca, T. C. O.; Saint'Pierre, T. D.; Spectrochim. Acta, Part B 2016, 119, 1.

42. de Souza, J. R.; Duyck, C. B.; Fonseca, T. C. O.; Saint'Pierre, T. D.; J. Anal. At. Spectrom. 2012, 27, 1280.

43. González, P.; Pérez, N.; Knochen, M.; Quim. Nova 2016, 39 , 305.

44. Duyck, C. B.; Saint'Pierre, T. D.; Miekeley, N.; da Fonseca, T. C. O.; Szatmari, P.; Spectrochim. Acta, Part B 2011, 66, 362.

Submitted: October 12, 2018

Published online: February 20, 2019 